http://dx.doi.org/10.12775/szhf.2013.037

\title{
Recepcja Kartezjusza w Hiszpanii ze szczególnym uwzględnieniem stanowiska José Ortegi y Gasseta
}

\section{Pierwsze recepcje Kartezjusza w Hiszpanii (wiek XVII i XVIII)}

Myśl Kartezjusza odegrała istotną rolę w rozwoju nauki i filozofii hiszpańskiej. Trudno jednak nie zauważyć, że jej recepcja była tam dużo mniejsza niż w innych krajach europejskich. Główny powód takiego stanu rzeczy to wzrastający od drugiej połowy XVII wieku kryzys hiszpańskiego życia politycznego, ekonomicznego, społecznego i intelektualnego. Źródeł kryzysu należy upatrywać przede wszystkim w silnym ruchu Kontrreformacji i związanej z nim rewitalizacji scholastyki, które skutecznie opóźniały, a nierzadko blokowały rozwój i recepcję nowych prądów w nauce i filozofii.

Mimo tej niewątpliwej dekadencji myśl nowożytna przedarła się do Hiszpanii, pozostawiając tam swój nieusuwalny ślad w postaci oddziaływania idei nowożytnych, w tym myśli Kartezjusza.

Pierwsze wzmianki o francuskim filozofie pojawiły się za Pirenejami po 1680 roku. Najważniejszymi ośrodkami badań nad nowożytną, a w tym kartezjańską filozofią były wówczas Królewskie Towarzystwo Medyczno-Naukowe w Sewilli (La Regia Sociedad de Medicina y Ciencias de Sevilla) ${ }^{1}$, które

${ }^{1}$ Historia powstania La Regia Sociedad de Medicina y Ciencias de Sevilla (Królewskiego Towarzystwa Medyczno-Naukowego w Sewilli) związana jest z osobą młodego medyka Juana Muñoza y Peralta, który w 1793 roku zrezygnował z piastowania katedry na Wydziale 
jako pierwsze w całej Hiszpanii wprowadziło przedmiot o nazwie Filozofia Nowożytna oraz Uniwersytet w Walencji (Universidad de Valencia), gdzie wykładali i tworzyli swoje prace najsłynniejsi XVII i XVIII-wieczni hiszpańscy matematycy, geometrzy i astronomowie, tacy jak: jezuita Bernardo José Zaragoza y Vilanova znany jako Ojciec Zaragoza (Padre Zaragoza), Tomás Vicente Tosca czy Juan Bautista Corachán.

Pierwszy z nich, José Zaragoza² zasłynął przede wszystkim za sprawą swoich odkryć astronomicznych. Był jednym z pierwszych w Europie obserwatorów komet. Obserwował komety w 1664 i w 1667 roku. O wynikach tych obserwacji pisano w „Journal des Savants” i w „Memoires” Akademii Nauk w Paryżu (Academia de Ciencias de Paris). Ponadto skonstruował on dwa typy lunet, które następnie wykorzystywał w swoich obserwacjach ciał niebieskich. Zaragoza miał też duże osiągnięcia w obszarze matematyki. Najprawdopodobniej znał on dokonania Kartezjusza, szczególnie te dotyczące geometrii analitycznej, jednak sam w swoich badaniach stosował metodę syntetyczną właściwą geometrii klasycznej.

Medycznym na Uniwersytecie w Sevilli (Facultad de Madicina de Sevilla). Powodem tego był przede wszystkim przestarzały program zajęć oraz zacofane metody uniwersyteckich działań. W ten sposób zajął się on organizacją spotkań postępowych lekarzy, które to spotkania przeszły do historii pod nazwą „Veneranda Tertulia Hispalense”. Po kilku latach „Veneranda Tertulia Hispalense" przekształciła się w La Regia Sociedad de Medicina y Ciencias de Sevilla, stając się jednym z najnowocześniejszych i najprężniej rozwijających się ośrodków naukowych w XVIII-wiecznej Hiszpanii. W XIX wieku otrzymała ona nową nazwę Real Academia de Medicina y Cirurgía (Królewska Akademia Medycyny i Chirurgii), pod którą działa do dziś.

${ }^{2}$ José Zaragoza (1627-1679), hiszpański jezuicki matematyk, astronom i kosmolog. Był członkiem grupy Novatores, czyli osób rozpowszechniających postępowe idee. Uznawany jest również za duchowego ojca hiszpańskich encyklopedystów. Jego główne dzieła to: Aritmetica universal que comprehende el arte menor y maior, algebra vulgar y especiosa, Jerónimo Vilagrasa, Valencia 1669; Trigonometria española: resolución de los triangulos planos y esfericos, fabrica y uso de los senos y los logaritmos, Francisco Oliver, Mallorca 1672; Canon trigonometricus. Contiens logarithmus sinuum, et tangentium, ad singula scrupula totius semicirculi. Radii Logarithmo 10.000000, Madrid 1672; Tabula logarithmica. Contiens undecim numerorum chiliades cum suis logaritmis ad unitate, scilicet, ad 11100. Dispositis nova methodo et proportioni astronomicae applicatis in gratiam astronomorum, Madrid 1672; Fabrica y uso de varios instrumentos mathematicos, Antonio Francisco de Zafra, Madrid 1675; Esphera en común celeste y terraquea, Juan Martín del Barrio, Madrid 1679; Geometria magna in minimis, in III partes divisa: I De Mininimis in communi: II De planis: III De Solidis, Toledo 1674. 
Drugi z wymienionych myślicieli, Vincente Tosca ${ }^{3}$ był matematykiem, kartografem i teologiem oraz współtwórcą nowego ruchu filozoficznego w Hiszpanii znanego jako Novatores (ruch nowatorów), który zajmował się rozpowszechnianiem nowożytnych europejskich prądów naukowych i filozoficznych, a jego głównym celem było stworzenie rzetelnej akademii matematycznej. Największym osiągnięciem tego myśliciela było jego dziewięciotomowe dzieło pt. Compendio Mathematico, które ujrzało światło dzienne 25 lat przed ukazaniem się Zasad matematyki Newtona.

Trzeci zaś, czyli Bautista Corachán ${ }^{4}$ to nie tylko drugi współtwórca ruchu Novatores, matematyk, astronom i fizyk, lecz pierwszy, który podjął się przełożenia na język hiszpański fragmentów prac Kartezjusza. Z dostępnych źródeł informacji, których jest niezwykle mało, możemy dowiedzieć się, że przetłumaczył on między innymi fragmenty Kartezjańskiej Rozprawy o metodzie.

\section{Kartezjusz w hiszpańskim neokantyzmie i w „Pokoleniu 1898” (wiek XIX)}

Istotny postęp w recepcji myśli Kartezjusza w Hiszpanii nastąpił w drugiej połowie XIX wieku. Co ciekawe, przyczynił się do niego rozwój hiszpańskiego ruchu neokantowskiego, którego wpływ zaczął ujawniać się po 1872 roku. Stało się to głównie za sprawą działalności José del Perojo y Figuerasa ${ }^{5}$, który studiował i doktoryzował się na Uniwersytecie w Heidelbergu u samego

\footnotetext{
${ }^{3}$ Vincente Tosca (1651-1723), hiszpański matematyk, kartograf i erudyta, współtwórca ruchu Novatores. Jego główne prace to: Compendio Mathematico, en que se contienen todas las materias mas principales de las ciencias, que tratan de la cantidad, Imprenta de Antonio Marín, Madrid 1727; Compendium Philosophicum, 1721; Tratado de la música especulativa y práctica, 1710; Tratados de Arquitectura Civil, Montea y Cantería y Reloxes, 1794.

${ }^{4}$ Bautista Corachán (1661-1741), hiszpański matematyk, fizyk, astronom. Jego główne dzieło to Arithmetica demonstrada theorico-practica, para lo mathematico y mercantile, Jaime de Bordazar, Valencia 1699.

${ }^{5}$ José del Perojo y Figueras (1850-1908) filozof, neokantysta, uczeń Kuno Fishera, studiował w Heidelbergu. W 1883 roku dokonał pierwszego hiszpańskiego przekładu Krytyki czystego rozumu. Zob. Obras de Kant. Crítica de la razón pura (Madrid 1883), poprzedzonego obszernym wstępem La Vida de Kant y de la Historia de los orígenes de la filosofía crítica, de Kuno Fischer. Był założycielem filozoficznego czasopisma „Revista Contemporánea”, popularyzującego filozofię krytyczną w Hiszpanii. Jego główne dzieło to Ensayos sobre el movimiento intelectual en Alemania (Madrid 1875), zawierające odniesienia do Kanta: Kant y los filósofos contemporáneos, Schopenhauera: A. Schopenhauer i Wundta: Objeto de la filosofía de nuestro tiempo. Guileermo Wundt.
} 
Kuno Fishera. Po powrocie do kraju zaczął on rozpowszechniać idee neokantowskie oraz ich nowożytne źródła, których doszukiwał się między innymi w myśli Kartezjusza. Bardzo ważną rolę w tym procesie odegrało założone przez Perojo przy współpracy z Manuelem de la Revillą ${ }^{6}$ czasopismo i wydawnictwo „Revista Contemporánea”, w ramach którego zaczęły pojawiać się liczne przekłady najważniejszych prac z obszaru historii filozofii. W ten sposób w 1878 roku w Madrycie w serii Biblioteki Perojo (Biblioteca Perojo) Kolekcja Filozofów Nowożytnych część pierwsza (Colección de Filósofos Modernos, parte 1) ukazały się pierwsze krytyczne i pełne przekłady prac Kartezjusza w tłumaczeniu Manuela de la Reviili wraz z jego obszernym wprowadzeniem. Były to: Rozprawa o metodzie (Discurso del método), Medytacje o pierwszej filozofii (Meditaciones metafísicas), Zasady filozofii (Los principios de la filosofía), Namiętności duszy (Las pasiones del Alma). W tym samym 1878 roku została opublikowana druga część hiszpańskich przekładów dzieł Kartezjusza również w tłumaczeniu i opracowaniu Revilli, w której skład weszły: Zarzuty uczonych mężów i odpowiedzi autora (Objeciones a las meditaciones metafísicas, respuestas de Descartes a las objeciones).

Ważną rolę w rozpowszechnianiu filozofii Kartezjańskiej w Hiszpanii odegrało również literacko-filozoficzne „Pokolenie 1898”, które zrodziło się na przełomie XIX i XX wieku. Powodem jego powstania był wielki kryzys, w jaki popadła Hiszpania po przegranej wojnie ze Stanami Zjednoczonymi i po upokarzającym dla niej Traktacie Pokojowym w Paryżu, wskutek którego utraciła ona swoje ostatnie kolonie. Do przedstawicieli tego „Pokolenia” zaliczyć możemy takie postaci, jak: dramaturg, filozof, powieściopisarz Mi-

\footnotetext{
${ }^{6}$ Manuel de la Revilla (1846-1881) - pisarz, poeta, krytyk literacki, profesor prawa i filozofii na Uniwersytecie Centralnym w Madrycie, współzałożyciel „Revista Contemporánea”. Znawca filozofii Krausego, Kanta i neokantyzmu. Członek Institución Libre de Enseñanza, tłumacz dzieł Kartezjusza na język hiszpański. Zob. Obras filosóficas de Descartes (Madrid 1878). Jego najbardziej znane prace to: El neo-kantismo en España. Ensayos sobre el movimiento intelectual en Alemania por Don José del Perojo, „Revista de España” 1875, nr 47, s. 145-157 oraz La filosofía española, „Revista de España” 1875, nr 5, s. 111-115.

${ }^{7}$ Pokolenie 1898 związane jest z działalnością takich postaci, jak: Miguel de Unamuno, Pío Baroja, Antonio Machado, Ramiro de Maeztu i Azorín. Ich twórczość uchodzi za reakcję na wydarzenia, jakie nastąpiły od 1898, czyli od momentu, gdy Hiszpania przegrała wojnę ze Stanami Zjednoczonymi, wskutek której utraciła swoje ostatnie kolonie. Wydarzenie to spowodowało głęboki kryzys niemal we wszystkich dziedzinach hiszpańskiego życia. Szerzej na temat tego Pokolenia piszą: Azorín, La generación del 98, Anaya, Salamanca 1961; Ricardo Baroja, Gente del 98, Editorial Juventud, Barcelona 1969; José Blanco Amor, La generación del 98, Falbo Editor, Buenos Aires 1966.
} 
guel de Unamuno, dziennikarz i krytyk literacki Ramiro de Maeztu czy poeta Antonio Machado.

Szczególnie ważna w obszarze recepcji filozofii nowożytnej okazała się intelektualna działalność Miguela de Unamuno. W swojej filozofii, prócz myśli Kierkegaarda, Schopenhauera i Nietzschego odwoływał się on do Kartezjusza, wykorzystując między innymi jego koncepcję metodycznego sceptycyzmu, ze szczególnym wskazaniem na metafizyczne ujęcie sceptyckiego argumentu snu $^{8}$. Należy jednak zaznaczyć, że stosunek Unamuno do powyższej koncepcji Kartezjusza i jego próby wyprowadzenia z niej słynnego twierdzenia cogito ergo sum był w przeważającej części krytyczny9 ${ }^{9}$ U francuskiego filozofa bowiem „ja”, które myśli miało charakter substancjalny, jest to substancja myśląca, a zatem coś stałego, niezmiennego i abstrakcyjnego. U Unamuno natomiast kartezjańskie res cogitans zostaje zastąpione przez pojęcie życia, które nie odnosi się do tego, co ogólne, abstrakcyjne i substancjalne, lecz wskazuje na konkretną ludzką egzystencję, na życie jednostkowego człowieka, którego on sam określa mianem „człowieka z kwi i kości”10. Stąd też argument snu, który u Kartezjusza pełni rolę w obszarze epistemologii, jako jej punkt wyjścia i służy odnalezieniu pewnego twierdzenia, którego nie można zakwestionować u Unamuno stanowi raczej punkt dojścia w jego koncepcji i wskazuje na nędzę, i słabość ludzkiego rozumu, a także na metafizyczne wyobcowanie i witalne zagubienie człowieka w świecie ${ }^{11}$.

\section{Intensyfikacja badań: recepcja Kartezjusza u José Ortegi y Gasseta (wiek XX)}

Bez wątpienia recepcja filozofii Kartezjusza w ujęciu Unamuno, była jak u niemal wszystkich jego poprzedników dość powierzchowna i niepełna. Dopiero wszechstronna działalność najsłynniejszego po Suárezie hiszpańskiego filozofa José Ortegi y Gasseta wyznacza decydujący etap oddziaływania tej myśli w Hiszpanii. Ortega bowiem jako pierwszy dokonał systematycznego ujęcia Kartezjańskiej refleksji, ukazując ją na historycznym tle i przedstawia-

\footnotetext{
${ }^{8}$ Zob. uwagi na ten temat w: Antoni Defez, Unamuno, Descartes y la hipótesis del sueño, „Revista de Filosofía”, vol. 32, nr 1 (2006), s. 7-20.

${ }^{9}$ Krytycznie o Kartezjuszu pisze Unamuno w swoim dziele pt. O poczuciu tragiczności życia wśród ludzi i wśród narodów, tłum. H. Woźniakowski, Kraków-Wrocław 1984, s. 42-43.

${ }^{10}$ Zob. tamże, s. 5-6.

${ }^{11}$ Zob. uwagi na ten temat w: tamże, s. 43.
} 
jąc z jednej strony, jej źródła i korzenie, z drugiej zaś kontynuacje i wpływ, jaki wywarła ona na rozwój filozoficznej myśli.

Ortega z kartezjańską filozofią zetknął się po raz pierwszy za sprawą wspomnianego już wcześniej wydawnictwa „Revista Contemporánea”, publikującego dzieła takich klasyków, jak Spinoza, Woltaire czy Kant. Dalsze studia nad Kartezjuszem kontynuował na niemieckich uniwersytetach ${ }^{12}$. Szczególnie ważna była dla niego recepcja tej filozofii w ujęciu szkoły marburskiej. Hermann Cohen i Paul Natorp upatrywali we francuskim myślicielu jednego z prekursorów Kantowskiego transcendentalizmu. „Filozofia Kanta - pisał Natorp w pracy Kant a szkoła marburska - należy do wielkiej duchowej rodziny, której rodowód sięga przynajmniej Platona i Parmenidesa. Spośród filozofów nowożytnych należy zaliczyć do niej nie tylko Kartezjusza i Leibniza, lecz w takim samym stopniu Galileusza, Huyghensa, Newtona, Eulera, niemal bez wyjątku będących uczonymi zorientowanymi filozoficznie"13. W ten sposób marburczycy poddawali prace Kartezjusza i innych myślicieli dość specyficznej interpretacji, starając się przede wszystkim ukazać te elementy, które potwierdzałyby ich wizje rozwoju historii filozofii. Ortega po wielu latach opisał swoje studia na Phillipin Universität w następujący sposób: „Było dużo ortopedii w marburskim sposobie myślenia. Brało się autora lub naukę - Kartezjusza lub matematykę czy prawoznawstwo - i zmuszało się je do mówienia velis nolis tego, co wcześniej ustalono, że mówiły”" ${ }^{14}$. Hiszpański filozof wskazywał też na ograniczony repertuar problemów, zagadnień i stanowisk, które wzbudzały zainteresowanie neokantowskich nauczycieli. „Marburg - pisał - był twierdzą neokantyzmu. Żyło się tam w filozofii neokantowskiej niczym w jakiejś oblężonej cytadeli, w nieustannym: Stój kto idzie! Wszystkich dookoła uważano za śmiertelnych wrogów: pozytywistów,

${ }^{12} \mathrm{O}$ studiach Ortegi na niemieckich uniwersytetach w Lipsku, Berlinie i Marburgu piszę w swojej najnowszej książce José Ortegi y Gasseta studia na niemieckich uniwersytetach, Aureus, Kraków 2012. Piszę o tym również w mojej dysertacji doktorskiej opublikowanej jako José Ortega y Gasset. Dziedzictwo Kanta i neokantyzmu marburskiego, Arboretum, Wrocław 2011, s. 133-154.

${ }^{13}$ P. Natorp, Kant a szkoła marburska, tłum. A. J. Noras, [w:] Neokantyzm badeński i marburski. Antologia tekstów, red. A. J. Noras i T. Kubalica, Wydawnictwo Uniwersytetu Śląskiego, Katowice 2011, s. 242-243.

${ }^{14} \mathrm{~W}$ niniejszej pracy korzystam z najnowszej edycji dzieł zebranych Ortegi y Gasseta: J. Ortega y Gasset, Obras completas, t. 1-10, ed. Fundación José Ortega y Gasset/Centro de Estudios Orteguianos, Fundación José Ortega y Gasset \& Taurus, Madrid 2004-2010. Cyt. z J. Ortega y Gasset, Prólogo para alemanes, [w:] tenże, Obras completas, t. 9 (1933-1948) Obra Póstuma, Taurus \& Fundación José Ortega y Gasset, Madrid 2009, s. 144. 
psychologistów, Fichtego, Schellinga i Hegla. Traktowano ich z taką wrogością, że nie chciano ich czytać. W Marburgu czytano tylko Kanta i przełożonych uprzednio na kantyzm Platona, Kartezjusza i Leibniza. Z pewnością te cztery nazwiska są wybitne, lecz nie można zredukować wszystkich soków Historii uniwersalnej do zaledwie kilku kropel"15.

Te marburskie interpretacje linii rozwoju filozofii z pewnością wpłynęły na rozważania Ortegi dotyczące Kartezjusza. Oddziaływanie to widoczne jest przede wszystkim w pierwszym etapie jego twórczości, przypadającym na lata 1902-1914, zwanym obiektywizmem ${ }^{16}$. Przykładem może tu być wygłoszony przez niego w 1908 roku, a następnie opublikowany odczyt pt. Descartes y el método transcendental ${ }^{17}$ (Kartezjusz i metoda transcendentalna), w którym wskazuje on na Kartezjańskie źródła metody transcendentalnej Kanta.

Punktem wyjścia swoich rozważań w tej pracy czyni hiszpański filozof neokantowskie twierdzenie o tożsamości myślenia (poznania) i bytu, które, jego zdaniem, stanowi podstawę wszelkiego idealizmu, w tym też stanowiska Kartezjusza. Jednocześnie zaznacza Ortega, że „poznanie” w Kartezjańskiej filozofii rozumieć należy bezwzględnie jako poznanie naukowe, na co wskazuje zmiana pojmowania pierwszej filozofii (prima philosophia), która od Kartezjusza przekształca się z metafizyki w teorię metody ${ }^{18}$. Ortega powołuję się tu na jeden z fragmentów VIII prawidła kierowania umysłem, który w polskim przekładzie brzmi: „Wszak żadne badanie nie może tu być pożyteczniejsze nad to, czym jest poznanie ludzkie i jak daleko ono sięga. Dlatego obecnie tę właśnie sprawę obejmujemy jednym tylko pytaniem i sądzimy, że należy je zbadać jako pierwsze ze wszystkich przy pomocy prawideł podanych poprzednio: tego zaś raz w życiu powinien podjąć się każdy, kto choć trochę kocha prawdę, ponieważ w badaniu tego zagadnienia kryją się prawdziwe narzędzia wiedzy i cała metoda" ${ }^{19}$. W ocenie Ortegi słowa te w sposób zasadniczy zrewolucjonizowały ówczesną filozoficzną refleksję i wprowadziły ją na nową drogę, którą następnie podążył i udoskonalił Kant.

\footnotetext{
15 Tamże, s. 136.

${ }^{16}$ Zob. propozycję periodyzacji filozofii Ortegi u J. Ferrater Mora, Ortega y Gasset. Etapas de una filosofía, Seix Barrlal, Barcelona 1973.

${ }^{17}$ J. Ortega y Gasset, Descartes y el método transcendental, [w:] tenże, Obras completes, t. 1 (1902-1915), Taurus \& Fundación José Ortega y Gasset, Madrid 2004, s. 390-397.

${ }^{18}$ Zob. uwagi Ortegi w: tamże, s. 392.

${ }^{19}$ Kartezjusz, Prawidła kierowania rozumem, tłum. L. Chmaj, Warszawa 1937, s. 57-58.
} 
Pojęciem kluczem w tej rewolucji jest „metoda”, która, jak pisze Ortega stanowi „treść badania nad bytem poznania" ${ }^{20}$, co w rezultacie uzasadnia twierdzenie o tożsamości myśli (poznania) i bytu. Zdaniem hiszpańskiego filozofa to samo przekonanie, które w VIII prawidle wyraził Kartezjusz, powtórzył również Kant we fragmencie B XXII, w którym napisał, że „Jest ona [Krytyka czystego spekulatywnego rozumu] traktatem o metodzie, nie zaś systemem samej nauki, ale mimo to wykreśla cały zarys tej nauki, zarówno, co do jej granic, jak i co do całego wewnętrznego jej uczłonowania" ${ }^{21}$. Ortega podkreśla jednak, że zarówno w ujęciu Kanta, jak i Kartezjusza metoda nie stanowi „Zwykłego instrumentu do poznania czegoś względem niej zewnętrznego, lecz jest ona samą treścią tego poznania"22, jego zawartością i stającym się bytem. Widzimy tu wyraźnie wpływ filozofii szkoły marburskiej z jej sposobem rozumienia metody jako ruchu i zmiany. „Filozofia jako metoda - pisze Natorp - oznacza dla nas właśnie to, że wszelki stały byt musi zostać rozłożony $\mathrm{w}$ procesie na ruch myślenia. Zarówno eleackie, jak i idealistyczne zrównanie bytu i myślenia dopiero wskutek tego traci pozór pustej tautologii, właściwie ustanawiającej byt $\mathrm{w}$ myśleniu, że pozwala unieruchomić myślenie w nowym, w powiązanym z rzeczami bycie. Właściwy idealizm nie jest wcale idealizmem bytu eleackiego, lecz idealizmem wiecznego stawania się bytem"23.

Dodatkowo Ortega za swoimi marburskimi mistrzami przyjmuje, że istoty idealizmu krytycznego czy też transcendentalnego Kanta należy szukać właśnie w myśli Kartezjusza i w jego koncepcji nauki uniwersalnej, która wskazuje na jedność poznania, a przez to na jedność świadomości naukowej. $\mathrm{W}$ ten sposób przywołuje on słowa francuskiego myśliciela zawarte w pierwszym prawidle kierowania umysłem: „Odróżniając - pisze Kartezjusz - nauki od siebie stosownie do różnicy ich przedmiotów, [ludzie] sądzili, iż należy badać każdą oddzielnie z pominięciem wszystkich innych. Pomylili się w tym oczywiście. Wszystkie bowiem nauki nie są niczym innym jak ludzką mądrością, która pozostaje zawsze jedna i ta sama, chociaż stosuje się do różnych przedmiotów [...] Jeśli więc ktoś chce zając się poważnie badaniem prawdy, nie powinien wybierać jakiejś pojedynczej nauki; wszystkie one bowiem są z sobą powiązane i od siebie nawzajem zależne" ${ }^{24}$. Nie inaczej postrzega ten problem sam Ortega, który jedności poznania i myślenia nie utożsamia

\footnotetext{
${ }^{20}$ J. Ortega y Gasset, Descartes y el método transcendental, s. 393.

${ }^{21}$ I. Kant, Krytyka czystego rozumu, tłum. R. Ingarden, t. 1, PWN, Warszawa 1986, s. (BXXII).

${ }^{22}$ J. Ortega y Gasset, Descartes y el método transcendental, s. 393.

${ }^{23}$ P. Natorp, Kant a szkoła marburska, s. 246.

${ }^{24}$ Kartezjusz, Prawidła kierowania rozumem, s. 87.
} 
z „jednością wyników nauk szczegółowych”25, lecz z jednością mądrości, o której pisał Kartezjusz, a którą najlepiej oddaje podstawowe pojęcie neokantyzmu marburskiego, czyli pojęcie jedności świadomości naukowej. Ono właśnie, zdaniem Ortegi, ugruntowuje z jednej strony jedność samego poznania, z drugiej zaś ostateczną jedność metody. „Wymóg - pisze Natorp - ostatecznej, lecz nieskończonej w swym postępowaniu jedności metody dany jest wraz z wymogiem metody samej. Jeśli nie myśli się o niej, to od razu nasuwa się wątpliwość, czy także filozofia w ogóle powstaje tylko jako zadanie. Zatem jej kondycję podają w wątpliwość wszyscy ci, którzy nie mogli wznieść się do tego ścisłego i trudnego wymagania jedności”" ${ }^{26}$. Sam Ortega natomiast pisze o tym w następujący sposób „Wszelkie problemy i rozwiązania, nazywane przez Kanta „transcendentalnymi” ograniczają się do ufundowania jedności naukowych metod w jedności naukowej świadomości. Naukę, która do tego dąży określił Kartezjusz mianem Science universalle"27.

Ortega przy całym swoim zapale zinterpretowania myśli Kartezjańskiej w duchu filozofii Kanta, dostrzega jednak zasadnicze ograniczenia tej myśli, które w rezultacie sytuują ją poza stanowiskiem idealizmu transcendentalnego.

Pierwszym z nich, jest bez wątpienia przyznanie „ja”, które Kartezjusz nazywa res cogitans charakteru substancjalnego. Podmiot poznający, podmiot myślący jest u Kartezjusza sam w sobie, jest rzeczą, bytem. U Kanta natomiast, podobnie jak później u neokantystów, myślenie nie stanowi substancji, lecz proces o charakterze fieri. Myślenie, jak pisze Natorp jest spontanicznością, samorzutnością, a wskutek tego, wytworem na podstawie nieskończoności, działaniem, funkcją ${ }^{28}$. Ortega natomiast już w nieco późniejszej swojej pracy z 1929 roku pt. Filosofía pura. Anejo a mi folleto Kanta naświetla i rozwija ten problem następująco: „Według Kanta - pisze - byty poznawalne nie są same w sobie, ale są tym, co my w nie wkładamy. Ich byt to nasz wkład. Jednak w odróżnieniu od Kartezjusza, podmiot, który zajmuje tę pozycję także nie jest sam w sobie. Ten wkład ma charakter intelektualny, to myślenie, i w ten sposób dochodzimy do słynnej, idealistycznej formuły: byt jest myśleniem"29. Zdaniem Ortegi dopiero u Kanta następuje zmiana podstawowego sensu py-

\footnotetext{
${ }^{25}$ J. Ortega y Gasset, Descartes y el método transcendental, s. 394.

${ }^{26}$ P. Natorp, Kant a szkoła marburska, s. 247.

${ }^{27}$ J. Ortega y Gasset, Descartes y el método transcendental, s. 394.

${ }^{28}$ Zob. Uwagi P. Natorpa w Kant a szkoła marburska, s. 249-251.

${ }^{29}$ J. Ortega y Gasset, Filosofía pura. Anejo a mi folleto Kanta, [w:] tenże, Obras completes, t. 4 (1926-1931), Taurus \& Fundación José Ortega y Gasset, Madrid 2005, s. 282.
} 
tania ontologicznego. Królewieckiego filozofa nie interesuje bowiem problem bytu rozumiany jako pytanie czym jest byt, lecz problem bytu jako predykatu, czymkolwiek by ów byt był. „Podmiot [u Kanta - D. L.] - pisze Ortega „wkłada” byt w uniwersum. Bez podmiotu nie ma bytu. Ten podmiot sam przez się i w sobie również nie będzie miał bytu, jeżeli sam go w siebie nie włoży. W ten sposób byt „rzeczy” zmienia się w akt”" ${ }^{30}$ Ta zmiana perspektywy, która pojawia się u Kanta wyznacza, zdaniem Ortegi, możliwość przezwyciężenia stanowiska idealizmu. Myśl Kantowska zawiera bowiem w sobie ukrytą ontologię, której nie dostrzegło pokolenie neokantystów, rozważające tę filozofię tylko epistemologicznie. I właśnie owa ontologia, wolna od interpretacji idealistycznej, od dylematu idealizm-realizm powinna, w opinii Ortegi, stać się podstawowym zadaniem rodzącej się nowej filozofii.

Drugie ograniczenie myśli Kartezjańskiej, które ściśle wiąże się z pierwszym, to jej ukierunkowanie na czystą matematykę jako na naukę wzorcową. Matematyka natomiast, jak stwierdza Ortega, ogranicza się tylko do rozważań ilościowych i nie zajmuje się istnieniem. „Ostatecznie - pisze on - Science universalle, czyli nauka o metodzie, jest u Kartezjusza jedynie ufundowaniem Mathesis universalis lub też nauki ilościowej"31. Ta filozoficzna perspektywa zmienia się dopiero u Kanta, który swoje rozważania wsparł na systemie mechaniki Newtona, zajmującej się „istniejącymi ciałami” ${ }^{2}$. W ten sposób w Kantowskiej filozofii myślenie funduje zarówno istotę (esencję), jak i istnienie (egzystencję), dzięki czemu Kant, w przeciwieństwie do Kartezjusza, nie musi odwoływać się do Boga, aby dowieść realnego istnienia ciał. Jak pisze Ortega, podsumowując niejako swój odczyt „Deux ex machina - idea Boga - nie jest w logice potrzebny i zostaje przeniesiony [przez Kanta - D. L.] w obszar Etyki, z której nikt już nie może go usunąć"33.

\footnotetext{
30 Tamże, s. 283.

${ }^{31}$ J. Ortega y Gasset, Descartes y el método transcendental, s. 395.

32 Tamże, s. 397.

${ }^{33}$ Tamże.
} 


\section{Abstract \\ The Reception of Descartes in Spain with Special Reference to the Role of José Ortega y Gasset}

Keywords: Descartes, reception, Ortega, Spain, Neo-Kantianism

The purpose of this paper is to present the reception of Descartes in Spain. The text is divided into three parts. In the first part I present the early reception of Descartes in Spain, which took place at the turn of the seventeenth and eighteenth centuries and is associated with the activities of such figures as José Zaragoza, Vicente Tosca or Bautista Corachán. The second part presents the nineteenth-century study of Cartesian philosophy, which is associated with the reception of Descartes in the Spanish Neo-Kantianism and Generation of 1898. In the third part I show the twentieth-century reception of Descartes, associated with the figure and activity of José Ortega y Gasset. 